\title{
METODE LATIHAN (DRILL) UNTUK MENINGKATKAN HASIL BELAJAR PESERTA DIDIK DALAM MENGGAMBAR AUTOCAD
}

\author{
Ferry Lesmana ${ }^{1},{\text { Maman Kusman², } \text { Ariyano }^{3} \text {, Uli Karo Karo }}^{4}$ \\ Departemen Pendidikan Teknik Mesin \\ Universitas Pendidikan Indonesia \\ Jl. Dr. Setiabudhi No. 207 Bandung 40154 \\ ferrylesmana@yahoo.com
}

\begin{abstract}
ABSTRAK
Tujuan penelitian ini adalah memberikan gambaran nyata terhadap hasil belajar peserta didik setelah diterapkan metode latihan. Metode yang penelitian yang digunakan yaitu penelitian tindakan kelas dengan merujuk kepada model Kemmis dan McTaggart. Hasil penelitian menunjukkan bahwa pembelajaran AutoCad dengan menerapkan metode latihan telah memberikan peningkatan yang baik. Sehingga menimbulkan perubahan yang positif bagi peserta didik terutama dalam hasil belajarnya baik pada aspek kognitif, afektif, dan psikomotor. Kesimpulan penelitian ini yaitu penerapan metode latihan dalam upaya untuk meningkatkan hasil belajar peserta didik dalam menggambar AutoCad adalah sangat efektif. Hasil belajar peserta didik di kelas XI TP I dapat meningkat setelah diterapkannya metode latihan.
\end{abstract}

Kata kunci: latihan, hasil belajar, autoCad, gambar

\section{PENDAHULAN}

Temuan dilapangan bahwa, pembelajaran menggambar AutoCad di kelas jauh dari kondisi ideal. Jumlah waktu mata pelajaran AutoCAD dalam satu minggu seharusnya 4x45 menit, akan tetapi pada kenyataannya peserta didik hanya melaksanakan pembelajaran yaitu 2x45 menit dalam satu kali pertemuan dengan sistem rolling bagi dua. Latihan menggambar AutoCad yang dilakukan saat ini di SMK Negeri 6 Bandung lebih menekankan siswa pada latihan satu jenis gambar kerja saja dalam satu semester. Permasalahan yang terjadi adalah latihan yang dilakukan selama ini kurang menerapkan latihan pada setiap kompetensi, meskipun gambar kerja yang diberikan kepada peserta didik sudah mewakili semua kompetensi menggambar AutoCad 2 Dimensi. Pemberian latihan seperti ini berdampak kepada hasil belajar siswa yang jauh di bawah KKM (Kriteria Ketuntasan Minimum) mata pelajaran produktif yaitu nilai 70.

Presentase nilai akhir tiap kelas sebelum diremedial tahun pelajaran 2007/2008 dan 2008/2009 sangat jauh dibawah standar ketuntasan minimum mata pelajaran produktif. Bagi

\footnotetext{
${ }^{1}$ Mahasiswa Departemen Pendidikan Teknik Mesin FPTK UPI

${ }^{2}$ Dosen Departemen Pendidikan Teknik Mesin FPTK UPI

${ }^{3}$ Dosen Departemen Pendidikan Teknik Mesin FPTK UPI

${ }^{4}$ Dosen Departemen Pendidikan Teknik Mesin FPTK UPI
} 
peserta didik yang belum memenuhi kriteria ketuntasan minimum harus mengikuti program remedial yang diberikan oleh guru yang bersangkutan.

Variasi latihan yang berbeda pada tiap pertemuan sesuai dengan pokok bahasan yang akan dibahas. Latihan yang akan dilakukan adalah dalam satu kali pertemuan akan diberikan satu gambar kerja sesuai dengan kompetensi yang akan dicapai pada waktu tersebut, sehingga situasi dan kondisi yang terjadi akan menjadi lebih baik dari latihan yang dilakukan sebelumnya. Latihan terbimbing dan pemberian arahan dalam mengerjakan tugas gambar, merupakan hal yang penting dilakukan seorang guru atau instruktur gambar AutoCad, sehingga hasil belajar dalam kemampuan atau keterampilan menggambar peserta didik dapat meningkat dan terasah dengan baik. Metode latihan yang diharapkan mampu mengatasi permasalahan yang ada khususnya dalam pembelajaran menggambar AutoCAD 2 dimensi yang berimplikasi pada peningkatan hasil belajar dalam keterampilan menggambar AutoCAD pada peserta didik.

Masalah yang teridentifikasi, yaitu: jumlah fasilitas komputer yang ada di ruang AutoCad terbatas yaitu hanya 20 paket komputer. Rendahnya hasil belajar pada nilai akhir peserta didik dalam keterampilan menggambar AutoCad 2D dengan metode konvensional. Metode yang digunakan saat ini belum menerapkan metode latihan yang sebenarnya. Tujuan penelitian ini adalah mengukur hasil belajar peserta didik dalam menggambar AutoCAD 2D dan keterlaksanaan aktifitas belajar menggambar AutoCAD 2D, serta untuk mengetahui efektifitas pembelajaran dengan penerapan metode latihan.

Metode latihan itu sendiri menurut beberapa pendapat memiliki pengertian sebagai berikut:Suatu teknik yang dapat diartikan sebagai suatu cara mengajar di mana peserta didik melaksanakan kegiatan latihan, peserta didik memiliki ketangkasan atau keterampilan yang lebih tinggi dari apa yang telah dipelajari (Rusman, 2011). Suatu kegiatan dalam rnelakukan hal yang sama secara berulang-ulang dan sungguh-sungguh dengan tujuan untuk memperkuat asosiasi atau menyempurnakan suatu keterampilan supaya menjadi permanen.

Metode latihan bertujuan agar kegiatan praktek yang dilakukan oleh peserta didik menjadi lebih bermakna yang berkenaan dengan daerah materi pembelajaran yang khusus dan menyediakan pengetahuan mengenai hasil belajar dengan cepat dan akurat (Sagala, 2009). Metode latihan memiliki kelebihan dan kelemahan pada proses pelaksanaannya. Kelebihan metode latihan adalah pembentukan kebiasaan yang dilakukan dengan metode ini akan menambah ketepatan dan kecepatan pelaksanaan. Pemanfaatan kebiasaan tidak 
memerlukan banyak konsentrasi dalam pelaksanaanya. Pembentukan kebiasaan membuat gerakan-gerakan yang kompleks, rumit menjadi otomatis (habitation makes complex movement more automatic). Kelemahan metode latihan adalah dapat menghambat bakat dan inisiatif peserta didik, karena peserta didik dibawa kepada konformitas dan diarahkan kepada uniformitas. Latihan yang dilakukan berulang-ulang merupakan hal yang monoton dan mudah membosankan. Membentuk kebiasaan yang kaku, karena murid lebih banyak ditujukan untuk mendapatkan ecakapan memberikan respons secara otomatis, tanpa menggunakan inteligensia.

Untuk kesuksesan pelaksanaan metode latihan, guru atau instruktur harus memperhatikan langkah-langkah atau prosedur yang disusun yaitu: gunakanlah latihan ini hanya untuk pelajaran atau tindakan yang dilakukan secara otomatis, ialah yang dilakukan siswa tanpa menggunakan pemikiran dan pertimbangan yang mendalam, tetapi dapat dilakukan dengan cepat seperti gerak refleks saja, seperti: menghafal, menghitung, lari, dan sebagainya. Guru harus memilih latihan yang mempunyai arti luas ialah yang menanamkan pengertian pemahaman akan makna dan tujuan latihan sebelum mereka melakukan. Latihan itu juga mampu menyadarkan siswa akan kegunaan bagi kehidupannya saat sekarang ataupun di masa yang akan datang, juga dengan latihan itu siswa merasa perlunya untuk melengkapi pelajaran yang diterimanya. Pada latihan pendahuluan instruktur harus lebih menekankan pada diagnosa, karena latihan permulaan itu kita belum bisa mengharapkan siswa dapat menghasilkan keterampilan yang sempurna. Latihan berikutnya guru meneliti kesukaran atau hambatan yang timbul dan dialami siswa, sehingga dapat memilih atau menentukan latihan mana yang perlu diperbaiki. Instruktur menunjukkan kepada siswa respon atau tanggapan yang telah benar dan memperbaiki respon yang salah (Dessy, 2005). Jika perlu guru mengadakan variasi latihan dengan mengubah situasi dan kondisi latihan, sehingga akan timbul respon yang berbeda untuk peningkatan dan penyempumaan kecakapan dan keterampilannya. Perlu mengutamakan ketepatan, agar siswa melakukan latihan secara tepat, kemudian diperhatikan kecepatan, agar siswa dapat melakukan kecepatan atau keterampilan menurut waktu yang telah ditentukan, juga perlu diperhatikan pula apakah respon siswa telah dilakukan dengan tepat dan cepat. Guru memperhitungkan waktu atau masa latihan yang singkat saja agar tidak meletihkan dan membosankan. Tetapi sering dilakukan pada kesempatan lain. Masa latihan itu harus menyenangkan dan menarik, bila perlu dengan mengubah situasi dan kondisi sehingga menimbulkan optimisme pada siswa dan kemungkinan rasa gembira itu 
bisa menghasilkan keterampilan yang baik. Guru dan siswa perlu memikirkan dan mengutamakan proses yang esensial atau pokok sehingga tidak tenggelam pada hal-hal rendah atau tidak perlu. Instruktur perlu memperhatikan perbedaan individual siswa, sehingga kemampuan dan kebutuhan siswa masing-masing tersalurkan atau dikembangkan, maka dalam pelaksanaan latihan guru perlu mengawasi dan memperhatikan latihan perseorangan.

Belajar merupakan suatu proses perubahan tingkah laku individu melalui interaksi dengan lingkungannya. Perubahaan tingkah laku yang dimaksud meliputi aspek-aspek pengetahuan, pemahaman, kebisaaan, keterampilan, apresiasi, emosional, etika dan sikap. Perubahan tingkah laku sebagai akibat dari proses belajar (hasil belajar) bersifat relatif menetap dan sesuai dengan tujuan yang telah ditemukan. Hasil belajar ini dapat berupa kemampuan intelektual, sikap, maupun keterampilan psikomotor (Sanjaya, 2006).

Evaluasi merupakan suatu kegiatan membandingkan objek yang dinilai dengan standar tertentu. Evaluasi dengan terlebih dahulu menjelaskan tentang mengukur dan menilai. Mengukur adalah membandingkan sesuatu dengan satu ukuran dan bersifat kuantitatif (Arikunto, 2007). Menilai adalah mengambil suatu keputusan terhadap sesuatu dengan ukuran baik buruk dan bersifat kualitatif. Sedangkan mengadakan evaluasi meliputi kedua langkah di atas, yaitu mengukur dan menilai. Dengan demikian evaluasi adalah menilai tetapi dilakukan dengan mengukur terlebih dahulu. Menggambar AutoCAD adalah kemampuan membuat, membentuk tanda-tanda tertentu di atas permukaan dengan menggunakan goresan dari alat gambar menggunakan beberapa teknik menggambar dengan menggunakan program AutoCAD. Dalam menggunakan program AutoCAD, ada beberapa hal yang harus dikuasai, seperti yang terpapar dalam buku panduan Menggambar Rancang Bangun Mesin dengan AutoCAD 2008, antara lain: harus mempunyai pengetahuan dasar teknik pemesinan, menguasai gambar teknik mesin dan menguasai operasi sistem windows.

\section{METODELOGI PENELITIAN}

Metode yang digunakan adalah metode penelitian tindakan kelas. Penelitian tindakan adalah kajian sistematik dari upaya perbaikan pelaksanaan praktek pendidikan oleh sekelompok guru dengan melakukan tindakan-tindakan dalam pembelajaran. Penelitian ini bertujuan untuk memecahkan permasalahan praktis yang berasal dari permasalahan yang nyata dan aktual yang terjadi dalam pembelajaran di kelas. Penelitian 
tindakan ini sifatnya bukan menyangkut hal-hal yang statis, tetapi dinamis, yaitu adanya suatu perubahan yang baik pada objek yang diteliti. Perubahan ini menghendaki adanya suatu perbaikan dari sistem sebelumnya atau dalam hal ini adalah hasil belajar peserta didik yang mengalami perubahan menjadi lebih baik dari hasil belajar yang sebelumnya. Perbaikan dilakukan untuk mempermudah tujuan yang diinginkan dengan dilaksanakannya suatu treatment.

Prosedur penelitian tindakan kelas dilaksanakan melatui beberapa tahapan yang digambarkan dalam beberapa siklus. Model penelitian tindakan kelas yang digunakan yaitu model yang dikembangkan oleh Kemmis dan Taggart dalam suatu sistem spiral atau dalam bentuk pengkajian berdaur siklus. Siklus model Kemmis dan Taggart di atas, tahapan yang akan dilaksanakan dalam penelitian ini, yaitu perencanaan (planning, tindakan (action, pengamatan (observations) dan refleksi (reflection).

\section{HASIL PENELITIAN}

Hasil belajar peserta didik merupakan gabungan hasil belajar aspek kognitif, aspek afektif dan aspek psikomotor. Data IPK yang sudah didapat dari ketiga aspek tersebut kemudian dicari rata-ratanya sehinggahasil belajar peserta didik dapat terlihat. Penilian menunjukkan data IPK rata-rata hasil belajar (Tabel 1) ketiga aspek pada tiap siklus.

Tabel 1. Hasil belajar tiga ranah

\begin{tabular}{|c|c|c|c|c|}
\hline \multirow{2}{*}{ No } & \multirow{2}{*}{ Hasil Belajar } & \multicolumn{3}{|c|}{ IPK } \\
\hline & & Siklus I & Siklus II & Siklus III \\
\hline 1 & Kognitif & 70,8 & 82,1 & 98,8 \\
\hline 2 & Afektif & 70,7 & 79,7 & 92,0 \\
\hline \multirow[t]{3}{*}{3} & Psikomotor & 65,1 & 82,3 & 96,7 \\
\hline & Rata-rata & 68,9 & 81,4 & 95,8 \\
\hline & Kategori & Sedang & Tinggi & Sangat Tinggi \\
\hline
\end{tabular}

Rata-rata peningkatan keterlaksanaan belajar metode latihan oleh guru, yaitu: siklus 1 sebesar 3,08, siklus 2 sebesar 3,24 dan pada siklus 3 meningkat menjadi sebesar 3,62. Perkembangan aktivitas guru dari siklus I sampai siklus III cenderung meningkat yaitu dari kategori baik ke kategori baik sekali.

Keterlaksanaan belajar metode latihan oleh peserta didik menunjukan perkembangan aktivitas peserta didik dari siklus I sampai siklus III cenderung meningkat yaitu dari 
kategori baik ke kategori baik sekali. Keterlaksanaan pembelajaran dengan metode latihan dapat jelas terlihat (tabel 2) perkembangananya.

Tabel 2. Keterlaksanaan belajar model latihan oleh guru

\begin{tabular}{clccc}
\hline \multirow{2}{*}{ No } & \multirow{2}{*}{ Aspek Pembelajaran } & \multicolumn{3}{c}{ Skor Aktifitas Belajar } \\
\cline { 3 - 5 } & & Siklus I & Siklus II & Siklus III \\
\hline 1 & Membuka pelajaran & 3 & 3 & 3 \\
2 & Menyajikan materi pelajaran & 2,5 & 3,25 & 4 \\
3 & Implementasi latihan (drill) & 2,5 & 3,5 & 4 \\
4 & Evaluasi & 3 & 4 & 4 \\
5 & Menutup pelajaran & 2,5 & 2,5 & 3,5 \\
\hline
\end{tabular}

Berdasarkan perhitungan terhadap data skor gain ternormalisasi, diperoleh besar skor gain ternormalisasi telah diringkas (Tabel 3).

Tabel 3. N-Gain pada tiap siklus

\begin{tabular}{ccc}
\hline Siklus & N-Gain & Efektitivitas \\
\hline I & 0,6 & Sedang \\
II & 0,66 & Sedang \\
III & 0,98 & Tinggi \\
\hline
\end{tabular}

Perkembangan efektivitas pembelajaran, dapat diketahui bahwa perkembangan efektivitas dari siklus 1 sampai siklus III cenderung meningkat dari kategori efektifitas sedang ke efektivitas yang tinggi, hal tersebut dapat terlihat dari nilai gain temormalisasi.

\section{PEMBAHASAN}

Hasil belajar peserta didik dapat dilihat dari rata-rata IPK hasil belajar dari aspek kognitif, aspek afektif, dan aspek psikomotor. Peningkatan hasil belajar peserta didik. Hasil belajar pada siklus I, IP $_{\mathrm{k}}$ rata-rata adalah 68,9 dengan kategori sedang. Ketika guru sedang menjelaskan materi, sebagian peserta didik kurang bisa mendengarkan penjelasan dari guru. Interaksi antara peserta didik dan guru masih terlihat kaku atau dirasakan kurang efektif banyak peserta didik yang kurang aktif ketika pernbelajaran sedang berlangsung. Sebagian peserta didik ada yang melakukan latihan dengan sungguh-sungguh dan sebagian melakukan latihan dengan asal-asalan tidak sesuai dengan perencanaan yang dibuat. Oleh karena itu, perlu dilakukan perbaikan pada siklus selanjutnya. 
Hasil belajar pada siklus II, IPK rata-rata adalah 8,4 dengan kategori tinggi. Pemberian latihan dan materi yang tidak terlalu sulit, mempengaruhi peningkatan hasil belajar pada siklus II. Namun, peningkatan hasil belajar ini dirasakan masih kurang karena, pertarna terdapat beberapa peserta didik yang rnemiliki nilai rata-rata di bawah kriteria kelulusan minimum yaitu nilai 70 , oleh karena itu, perlu dilakukan perbaikan pada siklus selanjutnya untuk menyempumakan metode latihan yang diterapkan agar proses pembelajaran berjalan dengan lebih baik lagi.

Hasil belajar pada siklus III IPK rata-rata adalah 95,8 dengan kategori sangat tinggi. Perbaikan yang telah dilakukan sangat mempengaruhi peningkatan hasil belajar pada siklus III ini. Peserta didik mulai sangat terbiasa dengan metode latihan yang diberikan, persiapan yang baik, perencanaan yang matang. Latihan yang dikerjakan dengan baik menentukan peningkatan hasil belajar ini. Sesuai dengan tujuan peneliti dalam penelitian ini yaitu meningkatkan hasil belajar dengan menerapkan metode latihan. Hasilnya sudah tercapai dengan adanya peningkatan rata-rata IPK sebesar 26,9\% dari siklus I sampai siklus III dari kategori sedang sampai dengan kategori sangat tinggi.

Pembelajaran siklus $\mathbf{I}$, terdapat beberapa kekurangan khususnya pada fase membuka pelajaran, implementasi latihan, dan menutup pelajaran, hal ini terjadi karena guru belum terbiasa dengan kondisi kelas dan guru masih dalam proses penyesuaian dengan peserta didik sehingga kurang maksimal dalam melakukan pembelajaran. Oleh karena itu, perlu adanya suatu perbaikan agar keterlaksanaan belajar yang dilakukan oleh guru menjadi lebih baik pada siklus atau pembelajaran yang akan datang. Perbaikan yang dilakukan adalah meningkatkan aktivitas guru pada saat membuka pelajaran, meningkatkan aktivitas guru ketika latihan berlangsung, dan meningkatkan aktivitas guru ketika menutup pelajaran (Slameto, 2003).

Pembelajaran siklus Il, guru mulai menunjukan peningkatan aktivitas pada fasefase pembelajaran yang dilaksanakan. Guru sudah mulai terbiasa dengan kondisi kelas, interaksi dengan peserta didik sudah mulai terlihat sehingga proses latihan pun berjalan dengan baik. Akan tetapi, masih ada sedikit pennasalahan pada saat latihan berlangsung dan ketika menutup pelajaran. Pembelajaran siklus III dilaksanakan oleh guru sebagai langkah perbaikan pada siklus II. Fase-fase pembelajaran sudah berjalan dengan sangat baik, yang ditunjukan dengan adanya peningkatan aktivitas guru. Secara garis besar bahwa keterlaksanaan belajar dengan metode latihan dari siklus I sampai 
siklus ke III yang dilakukan oleh guru cenderung meningkat dari kategori baik sampai dengan kategori baik sekali.

Proses pembelajaran tidak hanya dilakukan oleh guru, akan tetapi peserta didik pun melakukan proses pembelajaran dengan metode latihan. Keterlaksanaan belajar yang dilakukan peserta didik telah dilaksanakan dengan cukup baik oleh peserta didik dalam pembelajaran AutoCad 2D di dalam kelas, yang ditunjukan oleh hasil observasi. Secara garis besar, bahwa keterlaksanaan belajar dengan metode latihan dari siklus I sampai siklus ke III yang dilakukan oleh peserta didik cenderung meningkat dari kategori baik sampai dengan kategori baik sekali. Keterlaksanaan belajar metode latihan yang diterapkan ini, baik keterlaksanaan belajar yang dilakukan oleh guru dan peserta didik dapat disimpulkan bahwa, keterlaksanaan belajar metode latihan yang diterapkan dapat berjalan dengan baik dan dapat memperbaiki kekurangan yang terjadi pada siklus sebelumnya (Bahri dan Zain,2002).

Perkembangan efektivitas pembelajaran, dapat diketahui bahwa urutan perkembangan efektivitas dari siklus pertama sampai siklus ketiga cenderung mengalami peningkatan hal tersebut dapat terlihat dari nilai gain temormalisasi dari kategori sedang sampai kategori tinggi. Materi pembelajaran siklus I cenderung mudah, proses pembelajaran berjalan dengan baik, peserta didik hanya kurang mendapat arahan ketika menjalani proses latihan dan LKS yang diberikan hanya sebagian peserta didik yang mempelajarinya. Proses pembelajaran pada siklus II juga berjalan dengan baik, peserta didik sudah mulai mendapat arahan yang baik dan peserta didik sudah mulai terbiasa dengan latihan yang diterapkan. Proses pembelajaran siklus III berjalan dengan sangat baik, peserta didik sudah sangat terbiasa dengan latihan yang diberikan oleh guru yang didukung dengan interaksi yang baik antara peserta didik dengan guru ketika pemberian arahan. Keberhasilan peningkatan efektifitas pembelajaran ini tidak terlepas dari peran serta guru yang menerapkan metode latihan yang berbeda dari latihan-latihan sebelumnya.

\section{KESIMPULAN}

Kesimpulan penalitian ini yaitu hasil belajar, keterlaksanaan model, aktifitas belajar peserta didik, efektifitas pembelajaran dengan menggunakan metode pemelajaran latihan (drill) meningkat menjadi lebih baik. Hasil belajar peserta didik dengan metode latihan mengalami peningkatan tiap siklus. Keterlaksanaan model latihan oleh guru pada pelaksanaan belajar mengalami peningkatan tiap siklus. Aktivitas belajar peserta didik pada 
pembelajaran dengan metode latihan mengalami peningkatan tiap siklus. Efektifitas pembelajaran dengan menggunakan metode latihan mengalami peningkatan tiap siklus.

\section{DAFTAR PUSTAKA}

Arikunto, S. (2007). Dasar-dasar Evaluasi Pendidikan. Jakarta: PT Bumi Aksara.

Bahri, S. dan Zain, A. (2002). Strategi Belajar Mengajar.Jakarta: Rineka Cipta.

Dessy. (2005). Interactive Engagment Methods In Introductory Mechanics Courses. Tersedia: http://www.physics.indiana.edu/sdi/lEM-2b.pdf,accessed on (19 Agustus 2010).

Rusman. (2011). Model-Model Pembelajaran Mengembangkan Profesionalisme Guru. Jakarta: PT. Raja Grafindo Persada.

Sagala, S. (2009). Konsep dan Makna Pembelajaran. Bandung: CV. Alfabeta.

Slameto. (2003). Belajar dan Faktor-Faktor yang Mempengaruhinya. Jakarta: Rineka Cipta.

Sanjaya, W. (2006). Strategi Pembelajaran Berbasis Standar Proses Pendidikan. Jakarta: Kencana Prenda Media. 